\title{
Toxicity of Oil Slicks to Arctic Amphipods
}

\author{
M. BUSDOSH and R. M. ATLAS ${ }^{1}$
}

\begin{abstract}
A study was conducted to measure the toxicity of oil spills to Arctic amphipods. Exposure to oil resulted in death, especially if animals physically entered the slicks. Arctic diesel was more toxic than Prudhoe crude oil. Toxicity of Prudhoe crude oil was associated with the paraffinic and aromatic components. Exposure to the tarry asphaltic fraction of crude oil did not result in amphipod mortality.

RÉSUMÉ. Toxicité des nappes de pétrole pour les amphipodes de l'Arctique. On effectua une étude destinée à mesurer la toxicité, pour les amphipodes, du pétrole déversé dans l'Arctique. L'exposition au pétrole fut mortelle pour ces animaux, particulièrement s'ils avaient pénétré physiquement dans les nappes. Le diesel de l'Arctique s'avéra plus toxique que le pétrole brut de Prudhoe. La toxicité du pétrole brut de Prudhoe était liée à ses composants paraffiniques et aromatiques. L'exposition à la fraction asphaltique goudronneuse du pétrole ne fut pas mortelle pour les amphipodes.
\end{abstract}

РЕЗЮМЕ. Токсичность нефтлных плтен и арктические бокоплавы. Ивучвлось отравляющее действие нефтяных пятен на арктических бокоплавов. Попадание животных в участки, покрытые слоем пефти, приводит к их гибели. Арктическое дияельное топливо обладает более сильным токсическим дейтвием, чем сырая нефть Прадхо-Бей. Предполагается, что токсичность сырони нефти Прадхо-Бей свяаана с содержканием в нен парафиновых и ароматических соединений. Контакт со смолистой асфальтовой фрагцией сырод нефти не был для бокоплавов смертельным.

\section{INTRODUCTION}

Current exploitation of oil reserves in the North American Arctic may result in contamination of its coastal ecosystems with petroleum pollutants spilled either accidentally or in the course of routine operations. An uncontrolled blowout of an offshore well, such as has been drilled in the Mackenzie Delta area, could result in the contamination of a large portion of the Arctic Ocean. Large pools of contaminating oil may form under sea ice, and in near-shore areas oil may enter sediment following a spillage.

It is important to determine the potential ecologic effects of oil pollutants by performing oil toxicity studies with the aid of suitable bioassay organisms. In the present study Arctic amphipods were used. These are exceedingly important components of Arctic ecosystems (MacGinitie 1955). They are major detritivores, consuming massive amounts of dead plant and animal material. They themselves are important as food, being consumed by Arctic cod and other fishes, several species of birds, seals, and in some cases whales. Amphipods were used as bioassay organisms in an earlier study of the potential effects of oil spillages in the Canadian Arctic (Percy and Mullin 1975).

1Department of Biology, University of Louisville, Louisville, Kentucky 40208, U.S.A. 


\section{Test Organisms}

Gammarus zaddachi Sexton and Boeckosimus (=Onisimus auct.) affinis Hansen were chosen as bioassay organisms because they are the dominant amphipod species in coastal-pond and marine-lagoon ecosystems, respectively, located at Point Barrow, Alaska (Busdosh and Atlas 1975). G. zaddachi was collected in Nuwuk Pond and $B$. affinis in Elson Lagoon, by the use of baited traps and by seining. Animals used in this study were between thirteen and sixteen millimetres in total length. G. zaddachi was maintained for these studies at a temperature of $5^{\circ} \mathrm{C}$ and a salinity of ten parts per thousand $(\%)$. B. affinis was maintained at $5^{\circ} \mathrm{C}$ and $27 \%$. These conditions approximated the temperature and salinity at the time of collection. The animals were acclimated to them in the laboratory for one week before being used in toxicity testing.

\section{Exposure}

In vitro toxicity testing was conducted at $5^{\circ} \mathrm{C}$ in trays measuring $45 \mathrm{~cm}$ by 20 $\mathrm{cm}$, containing five litres of water from the site of collection of the organisms. Oxygen levels were monitored routinely with an oxygen meter, and the water was always found to be saturated. Thirty animals were placed in each tray. A nylon mesh screen was placed in half of the trays to prevent the animals from reaching the surface and entering an oil slick. Organisms were exposed to either Arctic diesel, Prudhoe crude oil, or the paraffinic, aromatic, or asphaltic components of Prudhoe crude oil. Fractionation of Prudhoe crude oil into its major component classes was accomplished by column chromatography (Atlas 1975). Arctic diesel and Prudhoe crude oil were added at concentrations of $0.1 \%$ volume for volume (v/v), Prudhoe crude oil paraffinic fraction at $0.08 \%(\mathrm{v} / \mathrm{v})$, Prudhoe crude oil aromatic fraction at $0.04 \%(\mathrm{v} / \mathrm{v})$ and Prudhoe crude oil asphaltic fraction at $0.01 \%$ weight for volume. The concentrations of Prudhoe crude oil fractions used reflect their relative weight percentages in the crude oil (Atlas 1975). Controls lacking added oil were included. All exposures were performed in replicate.

In situ testing was conducted in Nuwuk Pond using G. zaddachi. Cubic Plexiglas chambers, $30 \mathrm{~cm}$ on a side, were attached to a float such that the chamber tops were held $10 \mathrm{~cm}$ above the water surface. Screened openings allowed flow of water through the chamber but precluded entry or escape of amphipods. Fifty animals were placed in each chamber. Five millilitres (ml) of Prudhoe crude oil were added to each of two experimental chambers. No oil was added to control chambers.

\section{Toxicity}

Mortality and general activity were checked daily for in vitro tests and on the eleventh and twenty-first day of in situ tests. Organisms that appeared dead, i.e., lacked pleopod movement and failed to respond to touch, were removed to separate chambers and observed for an additional 24 hours. No recovery was ever noted. The necessity of this post-exposure observation has been demonstrated by Hansen and Kawatski (1976). Results are expressed in this study as 
percentages of organisms surviving at selected intervals: LT 50 signifies time to reach $50 \%$ mortality, and LT 100 - time to reach $100 \%$ mortality.

The respiration rates of the animals after one and seven days of in vitro exposure were determined by use of a Gilson respirometer. One amphipod and five millilitres of water drawn from the respective pollutant's shielded tray were placed in each flask. This allowed exposure to the correct pollutant-water mix, but avoided direct contact with the oil by the animals. After one hour of acclimation, rates of oxygen consumption were measured for six hours. Ten animals were measured each time for each shielded and unshielded pollutant. Weights were determined after twelve hours in a $70^{\circ} \mathrm{C}$ drying oven. The rates of oxygen consumption, recorded in microlitres per hour per milligram dry weight, were subjected to analysis of variance.

\section{RESULTS}

\section{Mortality}

Although amphipods did not appear to be either attracted or repelled by the presence of Prudhoe crude oil slicks, they would swim into them by chance, if not physically prevented from doing so. An LT 50 occurred in in vitro tests within four days for $B$. affinis that could enter Prudhoe crude oil slicks, and within eight days for organisms shielded from them (Fig. 1). An LT 100 of ten days occurred for both shielded and unshielded $B$. affinis exposed to Prudhoe oil slicks.

G. zaddachi that could physically enter the slick showed similar LT 50s and LT

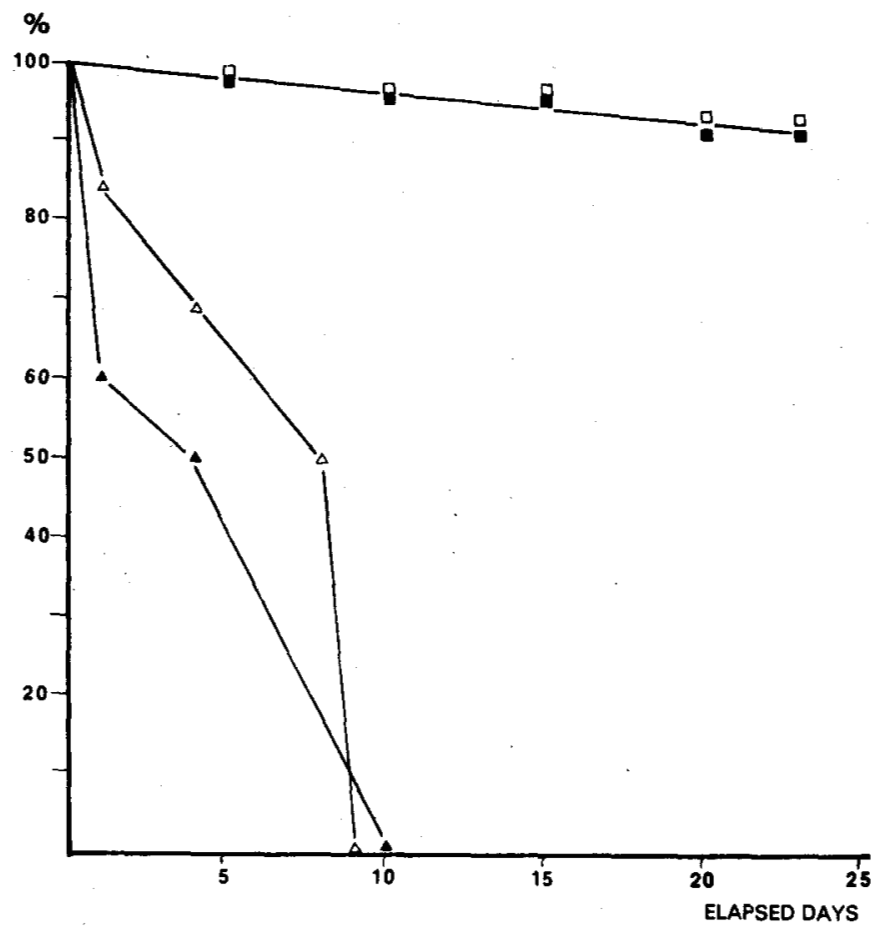

FIG. 1. Survival percentages of $B$. affinis exposed to Prudhoe crude oil in vitro (unshielded organisms are represented by black triangles, shielded by white triangles). The squares concern control chambers (unshielded organisms black, shielded — white). 
$100 \mathrm{~s}$ as $B$. affinis, five and ten days respectively (Fig. 2). G. zaddachi shielded from slicks were more tolerant of Prudhoe crude oil and failed to reach an LT 50 within two weeks. In situ testing of G. zaddachi also demonstrated their tolerance to the presence of Prudhoe crude oil slicks. Only organisms that became mired in the oil were killed. An LT 50 was not reached in the in situ testing within 22 days.

In vitro tests with $B$. affinis showed toxicity differences between major fractions of Prudhoe crude oil (Fig. 3). The paraffinic fraction was slightly more toxic than complete crude oil. Animals that could physically enter the clear paraffinic slicks appeared to do so by chance, and the result was an LT 50 of three days and LT 100 of four days. Shielding the animals from the slicks caused the LT 50 to increase to ten days and the LT 100 to twelve days. Within 48 hours, animals exposed to the paraffinic slicks secreted large amounts of a colourless mucus-like material; they all but ceased to move, and the gravid females among them shed their eggs.

Animals exposed to the aromatic fraction of Prudhoe crude oil avoided the slicks by veering away. Those exposed to them moved erratically and had difficulties in coordination after 48 hours. No difference was observed in mortality rates as between animals that could physically enter the slicks and those that were shielded from doing so; in both cases an LT 50 was reached at approximately fifteen days, and an LT 100 not within 23 days.

The asphaltic fraction of Prudhoe crude oil showed no apparent toxicity to amphipods, which crawled over gravel covered with the tarry asphaltic fraction and even appeared to scrape asphaltic components from gravel surfaces.

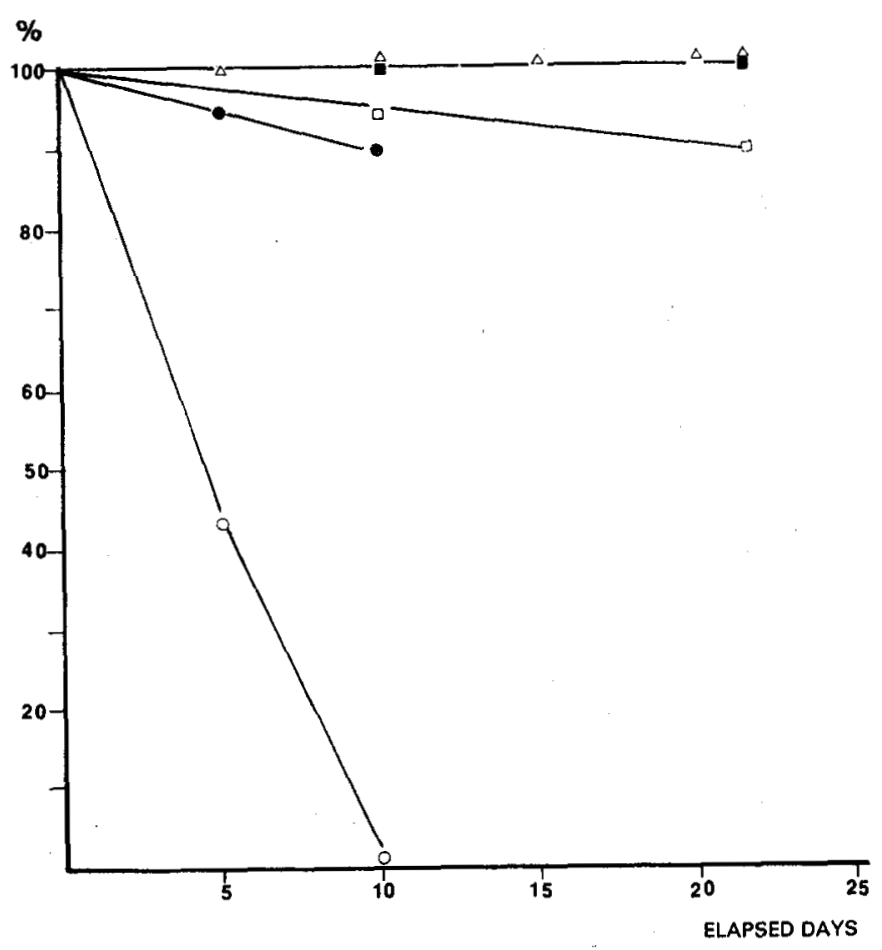

FIG. 2. Survival percentages of $G$. $z a d d a c h i$ exposed to Prudhoe crude oil in vitro (unshielded organisms white circles, shielded black circles) and in situ (unshielded - white square). The white triangles concern in vitro control chambers, the black squares - in situ controls. 


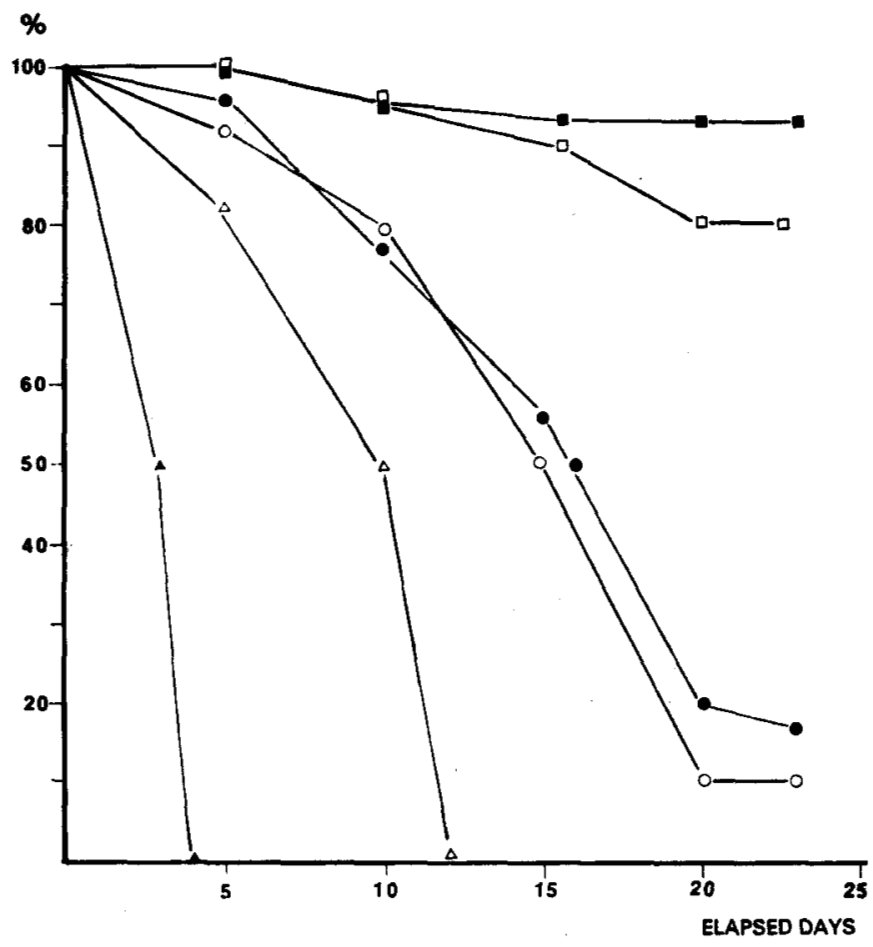

FIG. 3. Survival percentages of $\boldsymbol{B}$. affinis exposed to Prudhoe crude oil fractions. Paraffinic are represented by triangles, aromatic by circles and asphaltic by squares (black for unshielded organisms, white for shielded).

Exposure of $B$. affinis to Arctic diesel, a refined fuel used extensively in the Arctic, resulted in their rapid death if they could physically enter the slicks (LT 50 of one day, and LT 100 of two days) (Fig. 4). Shielding the animals from the slicks caused the LT 50 to be prolonged to fourteen days, and the LT 100 to fifteen days. Animals exposed to Arctic diesel developed difficulties in coordination similar to those observed in animals exposed to the aromatic fraction of Prudhoe crude oil, but did not exhibit any avoidance response.

\section{Respiration}

Respiration is a sensitive indicator of an animal's physiological and metabolic state. Respiration rates were lower in animals exposed to oil slicks than in control chambers (Table 1). Table 1 also shows the level of statistical significance of change from the controls after one and seven days exposure as determined in the analysis of variance. After they had been exposed for seven days to Prudhoe crude oil or Arctic diesel, their rates of oxygen consumption dropped below measurable levels. Amphipods exposed to the paraffinic fraction of Prudhoe crude oil showed a similar drop to below detectable rates of oxygen consumption within seven days, if they were allowed to enter the slicks, but only a $61 \%$ decrease occurred if they were shielded from them. Exposure for seven days to the aromatic fraction of Prudhoe crude oil resulted in a 60-70\% decrease in rates of oxygen consumption. While exposure of the animals to the asphaltic fraction did not result in their death, it brought about a $20-50 \%$ decrease in their rates of respiration. 


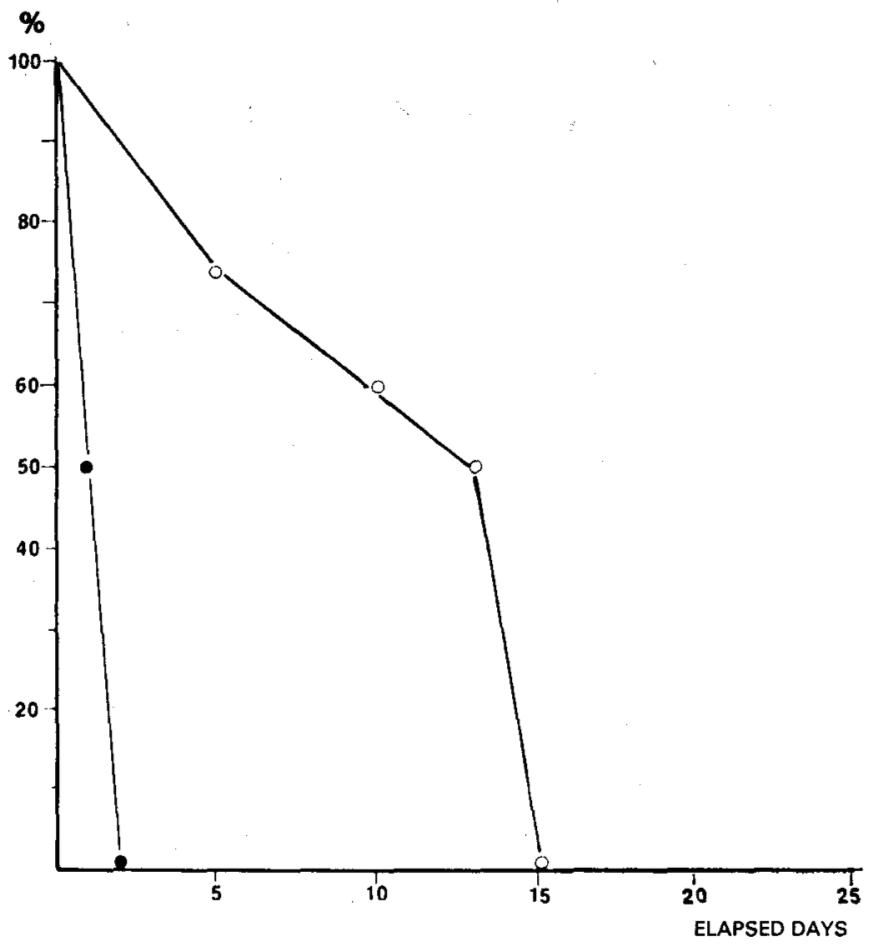

FIG. 4. Survival percentages of $\boldsymbol{B}$. affinis exposed to Arctic diesel refined oil (unshielded are represented by black circles, shielded by white circles). For control chambers see Fig. 1.

DISCUSSION

The results of this study show that amphipods that come in contact with oil slicks in the Arctic have little chance of survival. None survived being mired by oil. Percy (1974) has also found that amphipods are unlikely to recover after fouling by oil. Oil slicks entrapped under ice would be expected to be especially toxic to amphipods that feed on the underside of sea ice. Oil slicks overlying shallow nearshore areas, including the ecosystems of Arctic barrier-island lagoons

TABLE 1. Mean respiration rates and significance level of amphipods exposed to oil slicks (in microlitres of oxygen consumed per hour per milligram dry weight).

\begin{tabular}{|c|c|c|c|c|}
\hline \multirow[t]{2}{*}{ Treatment } & \multicolumn{2}{|c|}{ Exposure } & \multicolumn{2}{|c|}{$\begin{array}{l}\text { Significance level of } \\
\text { decrease from control }\end{array}$} \\
\hline & 1 day & 7 days & 1 day & 7 days \\
\hline Control & 2.25 & 2.29 & $\overline{01}$ & - \\
\hline $\begin{array}{l}\text { Crude - shielded } \\
\text { Crude - unshielded }\end{array}$ & 2.17 & $\simeq 0$ & .01 & 二 \\
\hline Paraffinic - shielded & 1.31 & 0.80 &.$\overline{01}$ &.$\overline{01}$ \\
\hline Paraffinic - unshielded & 0.82 & $\simeq 0$ & .01 & - \\
\hline Aromatic - shielded & 1.59 & $\overline{0.53}$ & .05 & .01 \\
\hline Aromatic - unshielded & 1.35 & 0.97 & .05 & .01 \\
\hline Asphaltic - shielded & 1.76 & 1.80 & * & .01 \\
\hline Asphaltic - unshielded & 1.03 & 1.29 & .01 & .01 \\
\hline Arctic diesel - shielded & 0.68 & $\simeq 0$ & .01 & .01 \\
\hline
\end{tabular}

"Not significant 
would also be expected to be especially detrimental, since even benthic amphipods could come into direct contact with them.

Comparison of survival rates of G. zaddachi in in situ and in vitro testing indicates proximity to the slick is of major importance. The in situ chambers contained water for a depth of $20 \mathrm{~cm}$ below the slick, while in vitro trays only had a depth of $10 \mathrm{~cm}$. This added distance, as well as the larger volume of the in situ chambers, allowed more animals to avoid becoming mired with oil.

Variations in the tolerance of species to oil slicks were noted in this study; $G$. zaddachi was more tolerant than $B$. affinis. Neither of these amphipod species however, exhibited any avoidance response to Prudhoe crude oil or Arctic diesel, which indicated that these animals could be expected to accidentally enter an oil slick in their natural habitats. Percy and Mullin (1975) have reported that $B$. affinis and $G$. oceanicus, which is closely related to $G$. zaddachi (Holmquist 1975), exhibit a high degree of avoidance to the crude oils that they tested, actual degree of avoidance depending on type of oil. In the present authors' studies, amphipods exhibited avoidance to the aromatic fraction of Prudhoe crude oil. Since different crude oils vary in percentage composition of paraffinic, aromatic, and asphaltic components, as well as in composition within each of these groups, degree of avoidance to a particular crude oil may be associated with the amount and types of aromatic components.

Amphipods may be able to avoid direct contact with a spill of a high aromatic oil, but since aromatic oil components are relatively water soluble, toxicity from such spills may be widespread. Nothing is known, however, of the detection and response mechanism of these animals to dissolved components of the oil.

Oil toxicity is generally attributed to the aromatic components of low molecular weight. Paraffins of low molecular weight cause narcosis (Moore and Dwyer 1973). The present study shows that paraffinic oil components are very toxic to Arctic amphipods. Paraffinic components are much less soluble, and would be expected to become diluted more slowly, but the current work indicates that high rates of amphipod mortality can be expected in areas in which oil slicks exist.

No lethality was observed when amphipods were exposed to the asphaltic fraction of Prudhoe crude oil. The asphaltic fraction, which is likely to be left following weathering and biodegradation of spilt oil, would sink to the bottom, coating sediment where it would come in contact with benthic organisms such as $B$. affinis for long periods of time.

The high toxicity of Arctic diesel observed in the experiments described in this paper, indicates that a spill of this fuel would only have to be present for a short time to result in large-scale mortality of Arctic amphipods. Several large spillages of refined oils have occurred in the Arctic. Barnett and Kontogiannis (1975) have reported that diesel fuels caused total mortality of temperate copepods within five days in laboratory tests and that diesel fuel was more toxic than kerosene, gasoline or benzene. While "white petroleum products", such as gasoline, kerosene and light diesel fuels, would be expected to be self-cleaning in temperate regions - that is, to undergo rapid evaporation and have a minimal period of residence in the ocean (Smith 1970) - spillage of such fuels in the Arctic can be expected to persist sufficiently long, due to reduced evaporation at low temperatures, 
adsorption onto sediment and entrapment under ice, to cause toxicity to amphipods.

In conclusion, spillages of crude or refined oils in the Arctic are likely to cause large-scale mortality of amphipods in the region of the spill, resulting in serious ecologic changes in decompositional processes and food-web relationships.

\section{ACKNOWLEDGEMENTS}

This work was supported by the U.S. Office of Naval Research. Logistic support was graciously supplied by the Naval Arctic Research Laboratory, Barrow, Alaska.

\section{REFERENCES}

ATLAS, R. M. 1975. Effects of temperature and crude oil composition on petroleum biodegradation. Applied Microbiology, 30: 396-403.

BARNETT, C. J. and xONTOGIANNIS, J. E. 1975. The effects of crude oil fractions on the survival of a tidepool copepod, Tigriopus californicus. Environmental Pollution, 8: 45-54. BUSDOSH, M. and ATLAS, R. M. 1975. Response of two Arctic amphipods, Gammarus zaddachi and Boeckosimus (= Onisimus) affinis, to variations in temperature and salinity. Journal of the Fisheries Research Board of Canada, 32: 2564-68.

HANSEN, C. R. and KAWATSKI, J. A. 1976. Application of 24-hour postexposure observation to acute toxicity studies with invertebrates. Journal of the Fisheries Research Board of Canada, 33: 1198-1201.

HOLMQUIST, c. 1975. Lakes of northern Alaska and northwestern Canada and their invertebrate fauna. Zoologische Jahrbücher: Abteilung für Systematik, Oekologie und Geographie der Tiere, 102: 333-483.

MacoINITIE, G. E. 1955. Distribution and Ecology of the Marine Invertebrates of Point Barrow, Alaska. Washington, D.C.: Smithsonian Institution (Smithsonian Miscellaneous Collections v. 128, no. 9).

MOORE, S. F. and DWYER, R. L. 1973. Effects of oil on marine organisms: a critical assessment of published data. Water Research, 8: 819-27.

PERCY, J. A. 1974. Effects of Crude Oil on Arctic Marine Invertebrates. Ottawa: Information Canada (Report to Environmental-Social Program, Northern Pipelines, on Project No. 11: Marine Ecology of the Mackenzie Delta and Tuktoyaktuk Peninsula Region, Part 2). and MULLEN, T. c. 1975. Effects of crude oil on Arctic marine invertebrates. Canada, Department of the Environment, Beaufort Sea Project, Technical Report no. 11 . SMITH, J. w. 1970. Dealing with oil pollution on the sea and on the shores. Coastal Water Pollution. Brussels: NATO, Committee on the Challenges of Modern Society. 